ELORE (ISSN 1456-3010), vol. $16-2 / 2009$.

Julkaisija: Suomen Kansantietouden Tutkijain Seura ry.

[http://www.elore.fi/arkisto/2_09/ajankoht_mckeough_2_09.pdf]

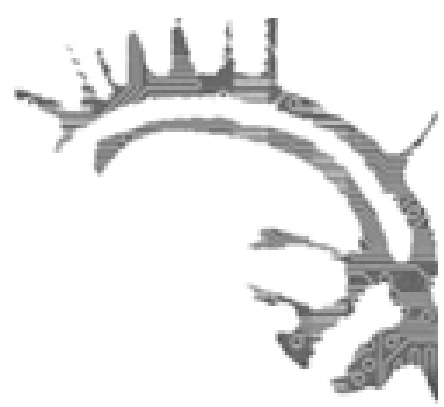

\title{
Ajankohtaista
}

\section{TYöVÄEN KIRJALLISEN KULTTUURIN JÄLJILLÄ}

Lukeva ja kirjoittava työläinen - Työväen historian ja perinteen tutkimuksen seuran kesäseminaari 24.-25.8.2009 Nurmijärvellä

\section{$\underline{\text { Andreas McKeough }}$}

Työväen historian ja perinteen tutkimuksen seuran (jatkossa THPTS) kesäseminaari Lukeva ja kirjoittava työläinen pidettiin perinteiseen tapaan elokuun lopussa Nurmijärven Kiljavanrannassa. Seminaarin esitelmät käsittelivät lukemisen ja kirjoittamisen merkityksiä ja käytäntöjä työväestön ja kansan keskuudessa. Esiintyjistä suurin osa oli historioitsijoita, mutta myös poliittisen historian, kulttuurihistorian, kirjallisuustieteen, folkloristiikan ja oikeustieteen edustajia oli paikalla. Seminaarin yleisilme oli siis tutun monitieteellinen. Paikalla oli nelisenkymmentä osallistujaa: tutkijoita, työväenhistorian harrastajia sekä arkisto- ja kirjastotyöntekijöitä.

Seminaari käynnistyi aurinkoisena elokuun aamupäivänä puheenjohtajan, tutkija Matti Hannikaisen avauspuheenvuorolla. Sen jälkeen kirjallisuudentutkija Kati Launis (Turun yliopisto) ja historioitsija Marko Tikka (Tampereen yliopisto) kertoivat toimittamastaan THPTS:n vuosikirjasta Työväkei ja kokemus - Väki Voimakas 22, joka julkaistiin seminaarissa. Julkistamisen ja esittelyn jälkeen artikkelin kirjaan kirjoittanut historioitsija Sami Suodenjoki esitteli oman artikkelinsa mielenkiintoista aihetta, omaperäistä suutari Lindholmia ja hänen asemaansa ja toimintaansa varhaisessa työväenliikkeessä.

\section{SEMINAARIN ENSIMMÄISEN PÄIVÄN ANTIA}

Päivän ensimmäinen seminaarin teemaan liittyvä esitys oli Suomalaisen Kirjallisuuden Seuran krjallisuusarkiston johtajan Anna Kuisminin key note -esitelmä Mitä, miten ja miksi kansa kirjoitti? Kuisminin esityksen kautta muodostui yleiskuva siitä, miten laajalti suomalaiset "kansanihmiset" aikojen saatossa ovat tarttuneet kynään sekä myös 
minkälaisia nämä kirjoitukset tyypillisesti ovat. Kuismin esitteli myös omia tutkimuksiaan: niiden sisältöä sekä sitä, miten hän oli päätynyt niiden pariin. Vaikka esitelmä oli tietoisena valintana tyyliltään luonnosmainen, välittyi siitä laaja-alainen tietämys ja ymmärrys aiheesta. Folkloristi Kirsti Salmi-Niklander (Helsingin yliopisto) täydensi kommenttipuheenvuorollaan Kuisminin esitelmää. Salmi-Niklander esitteli käsikirjoitettujen lehtien piirteitä asiantuntevasti ja muistutti, että ne ovat tutkimuksellisesti oivia aineistoja Kuisminin esittelemien kansan kynämiesten ja -naisten kirjoitusten rinnalla.

Lounaan jälkeen sosiaalihistorioitsija Kaisa Kauranen (Helsingin yliopisto, Suomalaisen Kirjallisuuden Seura) esitelmöi torppari Gunnar Braskin yhteiskunnallisista kirjoituksista. Esitelmässään Kirjoittava torppari Gustaf Brask ja bänen ybteiskunnalliset kirjoituksensa SKS:n kirjallisuusarkistossa Kauranen osoitti, miten Braskin (1829-1906) laaja tuotanto muodostaa hyvin mielenkiintoisen aineiston, sillä hän kirjoitti harvinaisen paljon ja monista aiheista. Braskin kirjoitusten ohella ja niiden ymmärtämiseksi Kauranen esitteli Braskin elämää sekä omia ja aikalaisten luonnehdintoja hänen persoonastaan. Seuraavana esitelmän piti kulttuurihistorioitsija Reija Lång (Turun yliopisto) aiheesta Ompelijasta oman kynän käyttäjäksi - kirjailija Matilda Roslin-Kalliola (1837-1923). Lång esitteli Roslin-Kalliolan tietä ompelijasta työläiskirjailijaksi, hänen kirjoittamisensa motiiveja sekä kirjallisen tuotannon ominaispiirteitä. Esitelmän kautta piirtyi Roslin-Kalliolan elämäntarinan ja valintojen ohella mielenkiintoinen kuva 1800-luvun kirjallisesta maailmasta, ennen kaikkea työläiskirjallisuudesta..

Kahvitauon jälkeen historioitsija Jaana Tornioja-Latola (Turun yliopisto) johdatti seminaariyleisön kahden nuoren työläisnaisen, Sylvi-Kyllikki ja Aina Sinervon maailmaan heidän päiväkirjojensa kautta esitelmässä Päiväkirja nuoren työläisperbeen tytön maailmankatsomuksen reflektointipaikkeana - Esimerk.keinä Sylvi-Kyllikeki ja Aira Sinervo. Näiden kahden kirjoitustaitoisen, kunniahimoisen ja romanttisen persoonan päiväkirjamerkintöjen ja -pohdintojen avulla Tornioja-Latola muodosti kuvan Sylvi-Kyllikin ja Airan elämistä ja ajatuksista sekä myös 1900-luvun alkupuolen yhteiskunnasta ja työväenkulttuurista. Työläisnaiset olivat aiheena seuraavassakin esitelmässä, jossa historioitsija Taina Uusitalo (Turun yliopisto) esitteli naisia käsitteleviä työläislehtien kirjoituksia. Uusitalo havainnollisti ja kategorisoi esitelmässään Äiti, nainen ja toveri - aatteellisuns velvoittaa naista työväenlebtien kirjoituksissa 1900-1930 niitä työläisnaisiin kohdistuneita ideaali- ja velvoitekonstruktioita, joita erityisesti naisille suunnatuissa työväenlehdistä on havaittavissa. Informatiivisessa esitelmässään Uusitalo esitteli myös muun muassa sosialistisen ja sosiaalidemokraattisen työväenlehdistön naisaiheisten kirjoitusten eroavaisuuksia.

\section{ENSIMMÄISEN SEMINAARIPÄIVÄN PÄÄTTEEKSI}

Ensimmäisen seminaaripäivän päätti Väinö Linna -aiheinen keskustelu- ja väittelytilaisuus. Paneelissa istuivat professori emeritus Yrjö Varpio, Anna Kuisimin ja kriitikko Lasse Koskela. Paneelin vetäjinä toimivat Matti Hannikainen ja Kati Launis. Panelistien avauspuheenvuorojen jälkeen Matti Hannikainen käynnisti keskustelun kysymällä panelistien näkemystä Väinö Linnan Täällä Pohjantähden alla -teossarjan suhteesta 
historian tutkimukseen: Kirjoittiko Linna teossarjansa historiallisena tutkimuksena? Kysymys herätti panelistien mielenkiinnon, ja pian keskustelu kävikin vilkkaana. Kysymys johdatti panelistit esittelemään tietoa ja pohdintoja Linnan kirjoitusmotiiveista sekä siitä, minkälaisten vaikutteiden ja innoitusten kautta Pohjantähti -teossarja sai alkunsa. Keskustelu polveili eri suuntiin, ja yleisö oli mielenkiinnolla mukana. Ennen kaikkea keskustelu Täällä Pohjantäbden alla-teossarjan henkilöhahmojen erityispiirteistä ja niihin lukiessa samaistumisesta sai yleisön innolla mukaan. Se, miten seminaariyleisö osallistui panelistien ohella keskusteluun vilkkaasti, antaumuksella ja henkilökohtaisia lukukokemuksiaan ja -tapojaan peittelemättä, osoitti, että aihe oli monelle henkilökohtaisesti tuttu ja tärkeä.

Ensimmäinen seminaaripäivän jälkeen iltaa istuttiin rantasaunalla saunoen, syöden ja virvokkeita nauttien. Kauniin auringonlaskun alla keskustelut palasivat usein päivän esitelmiin. Ennen kaikkea ne sivusivat Väinö Linna -teemaa. Ihmisten rentoutuessa ja illan pimetessä keskustelu sai uusia muotoja. Suurin osa illan puheenaiheista liittyi edelleen työväentutkimukseen, sen historiaan ja yleisestikin historiaan, mutta tunnelma oli huomattavan vapautunut ja keveä verrattuna aiempaan seminaarihuoneen asialliseen akateemisuuteen.

\section{TYÖläISINTELLEKTUELLEJA JA IDEOLOGiAA}

Toinen seminaaripäivä käynnistyi historioitsija Suvi Leppämäen (Helsingin yliopisto) esitelmällä Jean Guébenno ja työläisintellektuellin osa. Leppämäki kertoi esityksessään Guéhennon (1890-1978) elämästä ja elämäntyöstä, mutta myös laajemmin ranskalaisesta työväenintellektualismista, ennen kaikkea sen piirteistä maailmansotien välisenä aikana. Esitelmän jälkeen käytiin mielenkiintoinen keskustelu ranskalaisten ja suomalaisten työväenintellektuellien keskinäisistä vaikutussuhteista sekä heidän teostensa tyylillisistä ja sisällöllisistä eroista.

Leppämäen esitelmästä ja sitä seuranneesta keskustelusta oli luonnollista siirtyä kulttuurihistorioitsija Hanne Koiviston (Turun yliopisto) esitelmään Henkisiä aitureita. Koivisto käsitteli esitelmässään kolmen suomalaisen työväenintellektuellin, Jenny ja Paavo Pajusen sekä Lauri Vileniuksen elämää. Heidän paikoitellen hyvinkin dramaattisten elämäntarinoidensa ohella Koivisto hahmotteli seminaariyleisölle muun muassa näiden kolmen intellektuellin suhdetta toisiinsa, muihin työläisintellektuelleihin ja ajan suomalaiseen yhteiskuntaan.

Seuraavan esitelmän piti historioitsija Joni Krekola (Helsingin yliopisto) aiheesta Miten Yrjö Sirolasta tuli "SKP:n kaaderien isä"?. Krekolan systemaattinen ja perinpohjainen esitys piirsi kuulijoille esiin elävän kuvan Sirolan elämästä ja työstä. Sen kautta avautui näköala Sirolan elämään ja 1900-luvun alun suomalaiseen vasemmistopolitiikkaan, mutta ennen kaikkea Sirolan opetustyöhön Leningradissa ja Moskovassa. Lounaan jälkeen seurasi folkloristi Andreas McKeough'n (Helsingin yliopisto) esitelmä Vuoden 1918 sota työläisten kirjoituksissa.

Viimeisenä esitelmöi historioitsija Pia Koivunen (Tampereen yliopisto). Koivusen esitelmä Luku-ja kirjoitustaidon opetus 1920-1930-lukujen Neuvostoliitossa - Komsomolin 
lukutaitokampanjat ideologian juurruttamisen strategiana käsitteli lukutaitokampanjoita 1920- ja 1930-luvun Neuvostoliitossa. Koivusen asiantuntevan ja runsaasti esimerkkejä sisältävän esitelmän avulla hahmottui kuva sekä Neuvostoliiton sivistystasosta että sen kohottamiseksi räätälöidyistä kampanjoista. Tämän ohella esitys antoi mielenkiintoisen kuvan alkuajan Neuvostoliiton yhteiskunnasta.

Loppukeskustelussa Matti Hannikainen kyseli ihmisiltä palautetta päättyvästä seminaarista sekä ideoita seuraavan kesän seminaarin aiheeksi. Palaute oli positiivista, ja seminaariyleisön keskuudesta nousi myös esiin muutama idea seuraavaan kesän seminaarin aiheeksi.

Filosofian maisteri Andreas McKeough on folkloristiikan jatko-opiskelija Helsingin yliopistossa. 